\title{
Wear Resistance of Sintered Composite Hardfacings under Different Abrasive Wear Conditions
}

\author{
Taavi SIMSON*, Priit KULU, Andrei SURŽENKOV, Riho TARBE, Dmitri GOLJANDIN, \\ Marek TARRASTE, Mart VILJUS, Rainer TRAKSMAA
}

\author{
Department of Mechanical and Industrial Engineering, Tallinn University of Technology, Ehitajate tee 5, 19086 Tallinn \\ crossref http://dx.doi.org/10.5755/j01.ms.23.3.17640
}

Received 23 February 2017; accepted 19 June 2017

\begin{abstract}
The article focuses on vacuum liquid phase sintered (PM) composite hardfacings and their behaviour under different abrasive wear conditions. Hardfacings studied contained 30-50 vol \% fine, coarse or multimodal (fine and coarse) hardmetal reinforcement. For wear resistance studies, we used the Abrasive Rubber Wheel Wear (ARWW) test as a threebody abrasive wear test, the Abrasive Wheel Wear (AWW) test as a two-body abrasive wear test and the Abrasive-Impact Erosion wear (AIEW) test as an abrasive-erosive wear test. Tested materials were compared to Hardox 400 steel and CDP112 wear plate (Castolin Eutectic ${ }^{\circledR}$ Ltd.). It was found that under three-body abrasion conditions (ARWW test) hardfacings with high content of spehrical coarse reinforcement are suitable; their wear resistance is about two times higher than that of unreinforced hardfacings. Under two-body abrasive wear (AWW test), hardfacings with a high content of coarse reinforcement are recommended; their wear resistance is up to eight times higher than that of unreinforced hardfacings from the figures and graphs mentioned in the text. Under abrasive-erosive wear (AIEW test), unreinforced ductile materials are recommended; they have two to three times higher wear resistance than composite hardfacings reinforced with fine or multimodal reinforcement.

Keywords: hardfacing, powder metallurgy, abrasive wear, impact erosion.
\end{abstract}

\section{INTRODUCTION}

Hardmetal reinforced composite hardfacings provide efficient protection under different abrasive wear conditions $[1,2]$. Hardfacings containing coarse hardmetal reinforcment have been found particularly effective [3]. However, because of tungsten content and mining of it, hardmetals have impact on the environment; in addition, their price is increasing. Therefore, the aim is to find ways of recycling or reuse of hardmetal scrap [4]. Use of recycled industrial hardmetal waste has been studied in [5] as well.

Many scientists have studied composite hardfacings with $\mathrm{Ni}$, $\mathrm{Co}$ and $\mathrm{Fe}$ based matrixes [6-8]. Fe-based composite hardfacings are favoured due to their low price $[9,10]$.

Vacuum liquid phase sintering (PM technology) [3], plasma transferred arc welding (PTA) [11] and submerged arc welding (SAW) [12] have been proven to suit for production of those hardfacings. PM technology is safer for the operator, because of no ozone formation and UV radiation. Furthermore, no local deformation is caused by local heating; in PM technology all parts are heated equally.

Our previous research has focused on the effect of recycled hardmetal content in hardfacings [13] and on the effect of particle size and shape [14] on the wear resistance. Our findings indicate that the best results can be obtained with 30-50 vol\% coarse reinforcement content [13].

In this paper, focus is on the behaviour of composite hardfacings in wear conditions, with loose abrasive (analysed by the ARWW and AIEW test) and fixed abrasive (analysed by the AWW test). Results are compared to commercial materials (CDP 112 wear plate, Hardox 400 steel). Hardox 400 is chosen as reference material because it is common material in wear resistant steel structures such as jaw crusher or ball mills. CDP 112 is chosen as reference material so experimental hardfacings could be compared to existing commercial product.

Based on the results, conditions for use of composite hardfacings are specified and recommended. This research was conducted because to the authors` best knowledge, no studies have reported comparisons of hardfacings with coarse recycled hardmetal reinforcement in different abrasion conditions.

\section{EXPERIMENTAL}

\subsection{Feedstock materials and manufacturing of hardfacings}

Recycled (disintegrator milled) WC-Co hardmetal powder with fine and coarse fractions and commercial WCCo sintered spherical hardmetal as reinforcement and commercial iron-based self-fluxing alloy powder as matrix were chosen as feedstock materials to produce the hardfacings (see Table 1). Disintegrator milled hardmetal particles were angular in shape and had size of 0.16 to $0.31 \mathrm{~mm}$ (fine fraction) and 1.6 to $2.0 \mathrm{~mm}$ (coarse fraction). Commercial spherical hardmetal had a diameter of $2.8 \mathrm{~mm}$.

The layer of powder mixtures was layed on steel S235 (wt.\%: $0.17 \mathrm{C}, 1.40 \mathrm{Mn}, 0.55 \mathrm{Cu}, 0.025 \mathrm{P}, 0.012 \mathrm{~N}$, bal Fe) substrate and subjected to sintering in vacuum at $1100{ }^{\circ} \mathrm{C}$

\footnotetext{
* Corresponding author. Tel.: + 37258208242.

E-mail address: taavi.simson@ttu.ee (T. Simson)
} 
for $30 \mathrm{~min}$. Based on previous experiments [3], these parameters have been found to be optimal.

During the sintering process, self-fluxing alloy powder particles melt, while hardmetal particles remain unmelted. Melted self-fluxing alloy surrounds hardmetal particles and during cooling composite hardfacing is formed.

\subsection{Abrasive wear testing}

Three different wear testing methods were used to compare the wear resistance of produced hardfacings in wear conditions with a loose and fixed abrasive.

First, abrasive rubber wheel wear (ARWW) was used according to ASTM G65 [16] standard, other methods were experimental abrasive wheel wear (AWW) test [17], developed in Tallinn University of Technology, and abrasive-impact erosion wear (AIEW) test according to GOST 23-201-78 standard [18].

Table 1. Composition of hardfacings

\begin{tabular}{|c|c|c|}
\hline esignation & Composition, vol \% & Reinforcement size, $\mathrm{mm}$ \\
\hline$\overline{\mathrm{P} 1}$ & $100 \mathrm{FeCrSiB}^{\mathrm{b}}$ & - \\
\hline $\mathrm{C} 3$ & $30 \mathrm{WC}^{-\mathrm{Co}^{\mathrm{a}}}, 70 \mathrm{FeCrSiB}^{\mathrm{b}}$ & $1.6-2.0$ \\
\hline $\mathrm{C} 4$ & $40 \mathrm{WC}^{-\mathrm{Co}^{\mathrm{a}}}, 60 \mathrm{FeCrSiB}^{\mathrm{b}}$ & $1.6-2.0$ \\
\hline$\overline{\mathrm{C} 5}$ & $50 \mathrm{WC}^{-\mathrm{Co}^{\mathrm{a}}}, 50 \mathrm{FeCrSiB}^{\mathrm{b}}$ & $1.6-2.0$ \\
\hline S5 & 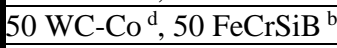 & $\mathrm{d}-2.8$ \\
\hline M5 & $50 \mathrm{WC}^{-\mathrm{Co}^{\mathrm{a}}, 50 \mathrm{FeCrSiB}}{ }^{\mathrm{b}}$ & $0.16-0.31 / 1.6-2.0$ \\
\hline F5 & $50 \mathrm{WC}^{-\mathrm{Co}^{\mathrm{a}}}{ }^{\mathrm{a}}, 50 \mathrm{FeCrSiB}^{\mathrm{b}}$ & $0.16-0.31$ \\
\hline $\mathrm{CDP}^{\mathrm{e}}$ & $\begin{array}{l}35 \mathrm{WC}, 65 \mathrm{NiCrSiB} \\
\text { (wt.\%) }\end{array}$ & - \\
\hline $\mathrm{H} 400$ & Steel ${ }^{\mathrm{c}}$ & - \\
\hline \multicolumn{3}{|c|}{$\begin{array}{l}{ }^{\mathrm{a}} \text { Experimental, from waste hardmetal } \\
\text { b } 6 \mathrm{AB} \text { from Höganäs } \mathrm{AB} \text {, with }+15-53 \mu \mathrm{m} \text { particle size; } \\
\text { 13.7 Cr, 2.7 Si, 3.4 B, 6.0 Ni, } 2.1 \mathrm{C}, \text { bal Fe. } \\
{ }^{\mathrm{c}} \mathrm{Hardox} 400 \text { steel, } 0.32 \mathrm{C}, 0.70 \mathrm{Si}, 1.60 \mathrm{Mn}, 0.025 \mathrm{P}, 0.010 \mathrm{~S} \text {, } \\
\text { 1.40 Cr, 0.60 Mo, 0.004 B, bal Fe } \\
{ }^{\mathrm{d}} \text { Commercial WC-Co, Wansheng Cemented Carbide Ltd. } \\
\text { e Wear plate CDP 112, Castolin Eutectic } ® \text { Ltd. [15] }\end{array}$} \\
\hline
\end{tabular}

Test results of abrasive rubber wheel wear (ARWW) show how composite hardfacings perform under abrasion with loose abrasive. It can be viewed as three-body abrasion.

Abrasive wheel wear (AWW) method is basically a testbody against a grinding wheel. This test shows how hardfacings perform under abrasion with fixed abrasive. AWW test can also be viewed as two-body abrasion.

Table 2. Parameters of wear tests

\begin{tabular}{|c|l|}
\hline Test & \multicolumn{1}{c|}{ Parameter } \\
\hline ARWW & $\begin{array}{l}\text { Velocity }-2.4 \mathrm{~m} / \mathrm{s} \text {, duration }-10 \mathrm{~min}, \\
\text { abrasive }- \text { silica sand, particle size } 0.2-0.3 \mathrm{~mm}, \\
\text { hardness } 1000-1100 \mathrm{HV}, \text { distance } 1440 \mathrm{~m}, \\
\text { quantity of abrasive }-3.75 \mathrm{~kg}\end{array}$ \\
\hline AWW & $\begin{array}{l}\text { Velocity }-2.4 \mathrm{~m} / \mathrm{s}, \text { duration }-10 \mathrm{~min}, \text { no free } \\
\text { abrasive, distance } 1440 \mathrm{~m} \text {, abrasive }- \text { SiC, particle } \\
\text { size } 600-800 \mu \mathrm{m}, \text { wheel hardness } 35 \mathrm{HRC}\end{array}$ \\
\hline AIEW & $\begin{array}{l}\text { Velocity }-80 \mathrm{~m} / \mathrm{s}, \text { impact angle } 30^{\circ}, \\
\text { abrasive }- \text { silica sand, partcile size } 0.2-0.3 \mathrm{~mm}, \\
\text { quantity of abrasive-6 kg }\end{array}$ \\
\hline
\end{tabular}

Abrasive-impact erosion wear (AIEW) test, similar to the ARWW test, uses loose abrasive but it can-not be viewed as three-body abrasion because except for the kinetic energy of impacting particles, no added force is acting upon testbodies.
Parameters of the ARWW and AWW (Table 2) were chosen as similar as possible such that the results could be compared. AIEW test parameters are presented in Table 2.

\subsection{Characterization of hardfacings}

Vickers macro- and microhardness of hardfacings were measured. Macrohardness HV30 (298 N) was measured to find the surface hardness and microhardness HV0.3 $(2.98 \mathrm{~N})$ was measured to find the matrix and hardphase microhardnesses separately. Results of hardness measurements are presented in Table 3.

Microstructures of received hardfacings were studied under scanning electron microscope (SEM) EVO MA-15 from Carl-Zeiss and using XRD analysis of C5 material.

\section{RESULTS AND DISCUSSION}

\subsection{Analysis of hardfacings microstructure}

SEM image of C5 in Fig. 1, S5 in Fig. 2, F5 in Fig. 3 and M5 in Fig. 4. Structures of C3 and C4 are simillar to C5 and therefore their SEM images are not given.

Hardfacings are characterized by cracks shown in Fig. 1 - Fig. 4

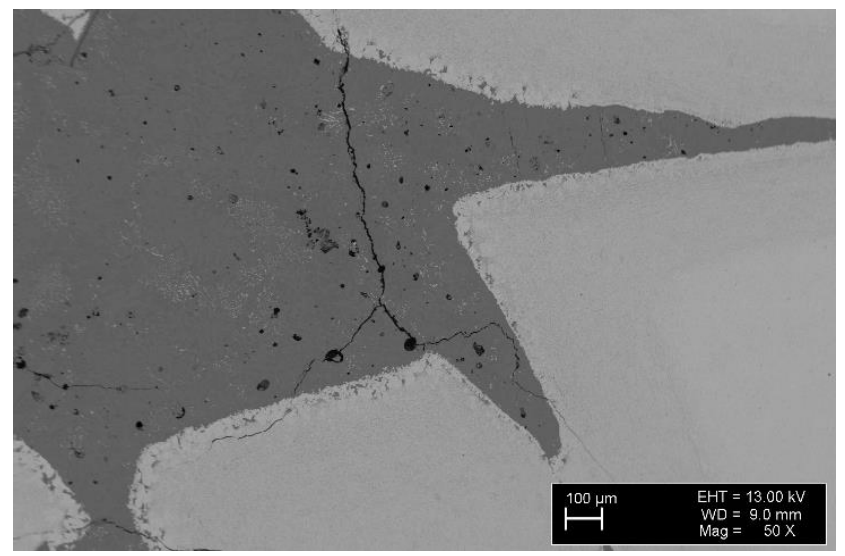

Fig. 1. SEM image of microstructure of C5: I-dissolutionpercipitation zone; II-diffusion zone; III-core zone of hardmetal particle

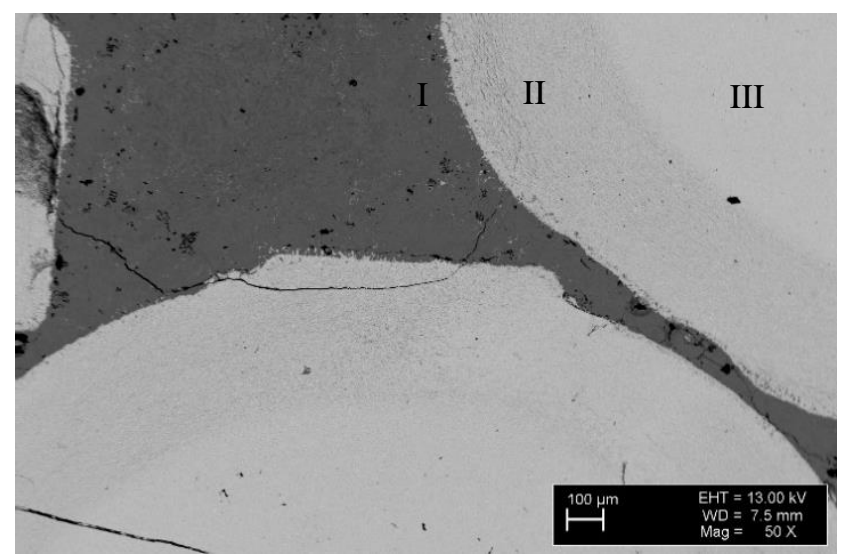

Fig. 2. SEM image of microstructure of S5

They are caused by different thermal expansion coefficients of $\mathrm{FeCrSiB}$ matrix and hardmetal reinforcement [3]. Hardfacings containing finer reinforce-ment (Fig. 3, Fig. 4) have higher porosity. Porosity is most likely to be caused by entrapped moisture as well as by different 
shrinkage of the components [19]. Most of the pores, those that are large and uneven in shape, are shrinkage pores. Small and round pores are caused by moisture evaporation [3]. In Fig. 1, Fig. 2 and Fig. 4, dark and lighter gray areas can be seen on hardmetal particles (pointed out in Fig. 1). These areas represent different zones in the contact area of the matrix and hardmetal particles. In zone (I), dissolution of cobalt and WC into a matrix and formation of new carbides takes place. This is caused by reactions between self-fluxing alloy and carbides and cobalt, due to corrosive nature of molten matrix material. In diffuson zone (II), Co is substituted by iron from the matrix. Size of diffusion zone is dependant on sintering temperature and time, the bigger the heat input, the larger the diffusion zone. Temperature in the diffusion zone is not high enough to cause the dissolution of WC, but is high enough to cause cobalt difusion. This is why sintering temperature is chosen high enough to cause matrix melting but low enough to avoid to big diffusion zone. No changes take place in the core zone (III). This is due to fact that temperature in core zone is not high enough to cause any changes to hardmetal.

XRD analysis showed that new carbides form during sintering process. Most noticeable were $\mathrm{Fe}_{5} \mathrm{C}_{2}$ and $\mathrm{Fe}_{23} \mathrm{C}_{6}$. Phases formed due to dissolution of hardmetal were $\mathrm{Cr}_{0.04} \mathrm{Fe}_{0.955}$, WcoB and $\mathrm{Cr}_{2.4} \mathrm{~W}_{0.6} \mathrm{~B} 4$ and $\mathrm{CrB}$.

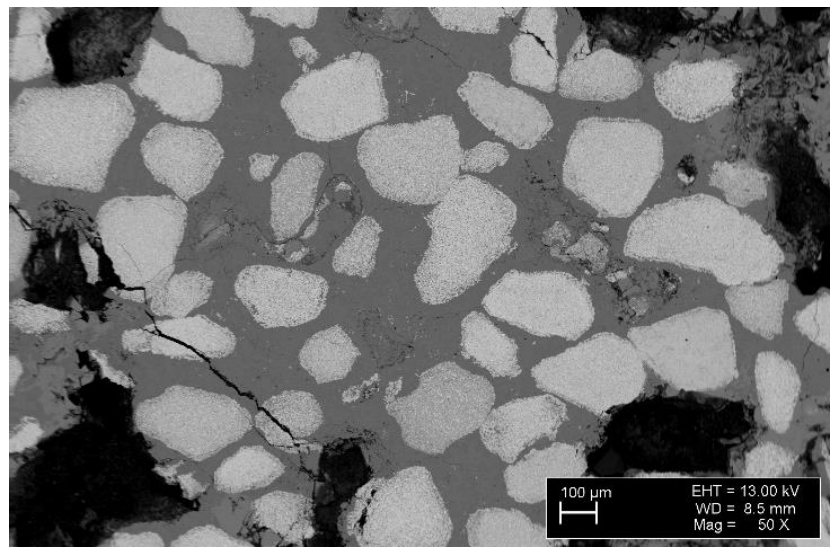

Fig. 3. SEM image of microstructure of F5

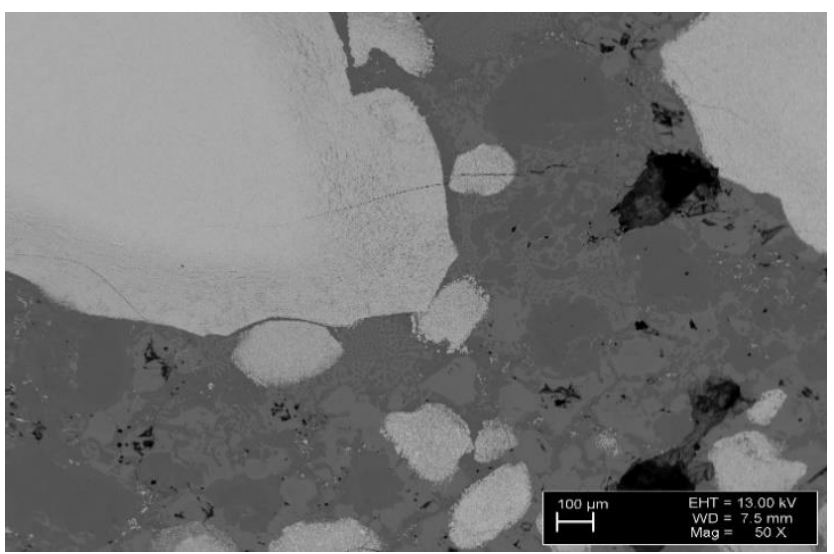

Fig. 4. SEM image of microstructure of M5

\subsection{Analysis of hardness measurements}

Results of materials hardness are presented in Table 3. Hardfacings with smaller reinforcement content have lower macrohardness. Hardfacings reinforced with fine or multimodal reinforcement also have lower macrohardness. Differences in reinforcement microhardness are caused by different cobalt binder content in hardmetal scrap used. Porosity influences microhardness of the matrix (F5 and M5) and to some extent macrohardness. There in no large difference in the microhardness values of reinforcement in the case of commercial and recycled hardmetal.

Table 3. Hardness of studied materials

\begin{tabular}{|c|c|c|c|}
\hline \multirow{2}{*}{ Designation } & Macrohardness, & \multicolumn{2}{|c|}{ Microhardness, HV0.3 } \\
\cline { 3 - 4 } & HV30 & Matrix & Reinforcement \\
\hline P1 & $868 \pm 28$ & $1035 \pm 70$ & - \\
\hline C3 & $1098 \pm 308$ & $978 \pm 54$ & $1444 \pm 136$ \\
\hline C4 & $1154 \pm 351$ & $1047 \pm 68$ & $1911 \pm 135$ \\
\hline C5 & $1260 \pm 436$ & $1005 \pm 41$ & $1856 \pm 67$ \\
\hline S5 & $1161 \pm 420$ & $950 \pm 107$ & $1637 \pm 117$ \\
\hline M5 & $1714 \pm 296$ & $817 \pm 63$ & $1482 \pm 126$ \\
\hline F5 & $830 \pm 161$ & $900 \pm 90$ & $1444 \pm 136$ \\
\hline CDP & $548 \pm 50$ & $524 \pm 111$ & $1730 \pm 318$ \\
\hline H400 & $425 \pm 25^{\text {a }}$ & - & - \\
\hline${ }^{a}$ Manufacturer data & \\
\hline
\end{tabular}

\subsection{Analysis of wear results}

Results of the ARWW and AWW test are presented in Table 4 and results of the AIEW test in Table 5. As can be seen from the results, in the ARWW test, the wear rates are much higher than the results of the AWW test.

One of the reasons is that during the ARWW, the abrasive particles move freely and are pushed into the softer matrix by the rubber wheel. This results in cutting away the matrix and some hardmetal particles becoming loose, contributing to higher wear rate.

In the AWW test, on the other hand, abrasive particles are embedded in the abrasive wheel. This means that abrasive particles cannot reach to cut away the matrix and therefore hardmetal particles in the matrix are more effective protecting the surface from the wear.

Interesting phenomena can be seen when comparing Hardox 400 and P1 hardfacing. In the ARWW test conditions where there is loose abrasive and macrohardness and resistance to cutting plays more importnat role, P1 is more wear resistant. In AWW where abrasive particles are fixed, Hardox 400 is more wear resistant on the basis of received results. However, the reason for that is yet unknown.

Similar trends can be seen when comparing self-fluxing alloy hardfacing P1 and commercial composite wear plate CDP112. In the ARWW test, material P1 is more wear resistant, in the AWW test, it is material CDP 112. Material CDP112 is more wear resistant thanks to WC particles in the matrix, which make the surface of CDP 112 more wear resistant. Reasons for better performance of Hardox 400 compared to P1 in AWW need a further study.

In the AIEW tests steel Hardox 400 seems to be the best material, because it is more available than CDP 112 and the difference in their wear resistance is small. Self-fluxing alloy hardfacing P1, even though it is harder than Hardox, gives only a small advantage in abrasive-erosive wear conditions. The reason is that high hardness from carbides that form during the sintering process lower the fatigue resistance of the material. Fatigue plays a role in erosion wear when impacting particles have lower hardness or their 
hardness is only slightly higher than the material they wear [20, 21].

Reinforcement particle size, at AIEW using fine or a mixture of fine and coarse reinforcement, is even detrimental to the results and gives no benefit. Using coarse reinforcement gives only a small benefit as compared to Hardox 400 and no benefit compared to a pure self-fluxing alloy. Therefore, it can be seen that in the abrasive-erosive wear conditions, unreinforced hardfacings with high ductility are beneficial while composite hardfacings should not be used in these conditions.

Table 4. ARWW and AWW test results

\begin{tabular}{|c|c|c|}
\hline \multirow{2}{*}{ Designation } & \multicolumn{2}{|c|}{ Wear, $\mathrm{mm}^{3}$} \\
\cline { 2 - 3 } & ARWW & AWW \\
\hline P1 & 4.99 & 6.15 \\
\hline C3 & 4.44 & 1.43 \\
\hline C4 & 5.93 & 0.68 \\
\hline C5 & 3.90 & 0.46 \\
\hline S5 & 2.92 & 1.02 \\
\hline M5 & 8.66 & 3.18 \\
\hline F5 & 10.91 & 2.98 \\
\hline CDP112 & 11.8 & 0.67 \\
\hline Hardox 400 & 57.5 & 3.66 \\
\hline
\end{tabular}

Table 5. AIEW test results

\begin{tabular}{|c|c|}
\hline Designation & Wear rate, $\mathrm{mm}^{3} / \mathrm{kg}$ \\
\hline $\mathrm{P} 1$ & 26.9 \\
\hline C5 & 30.2 \\
\hline M5 & 76.3 \\
\hline F5 & 90.3 \\
\hline H400 & 32.8 \\
\hline
\end{tabular}

Relative volumetric wear resistance $\varepsilon$ at the ARWW, AWW and AIEW test was compared to that of Hardox 400. Results are given in Fig. 6 - Fig. 8.

As can be seen, at the ARWW test, the differences are much higher. With the exception of $\mathrm{C} 4$, the rule of thumb is that the coarse hardmetal reinforcement the hardfacing contains, the higher the wear resistance of the hardfacing is. This is true to a certain extent, as too much reinforcment weakens the hardfacing. An optimal reinforcement content with coarse reinforcement seems to be around $50 \mathrm{vol} \%$, which is in good agreement with the previous results [8].

At the AWW test, the differences between the wear of materials are smaller than at the ARWW test. Again, it can be seen that the higher the coarse hardmetal content the higher the wear resistance.

When comparing a composite hardfacing with a pure self-fluxing alloy (P1), in the ARWW test, reinforcement in the matrix gives only minor improvement in the wear resistance. At the AWW test or two-body abrasion on the other hand, additional reinforcement in the matrix gives a multi-fold increase in the wear resistance. Therefore, in the three-body abrasion, unreinforced hardfacings seem to be more reasonable and in the two-body abrasion composite hardfacing have the advantage.

At the AIEW test, P1 gives only a small increase in the wear resistance as compared to Hardox 400. Using coarse reinforcement (C5) does not improve wear resistance and using fine or multimodal reinforcement in fact decreases the wear resistance of the hardfacing. Thus, in abrasion impact conditions steel or pure self-fluxing alloy gives the best results in terms of wear resistance.

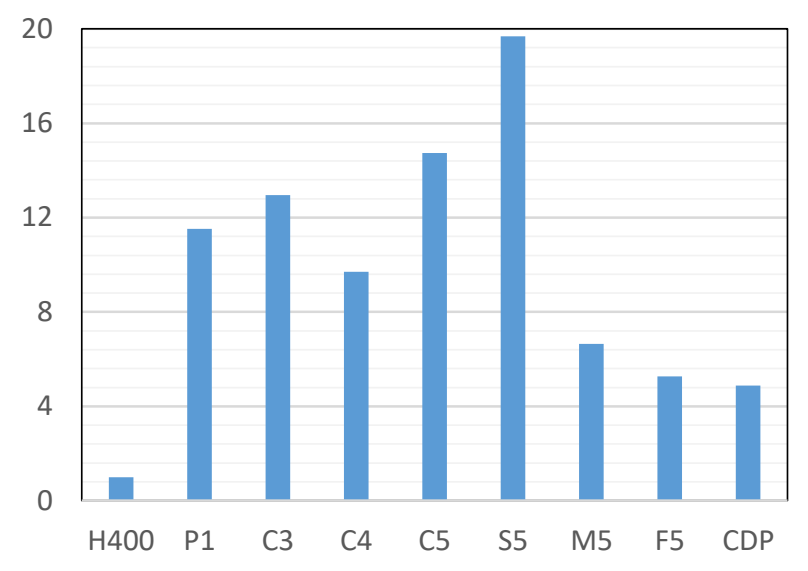

Fig. 6. Relative wear resistane $\varepsilon$ at ARWW test compared to Hardox 400

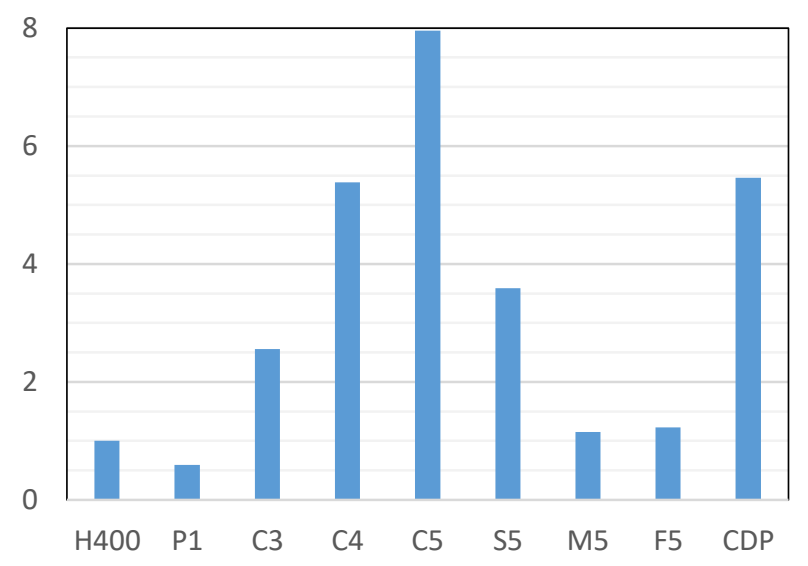

Fig. 7. Relative wear resistance $\varepsilon$ at AWW test compared to Hardox 400

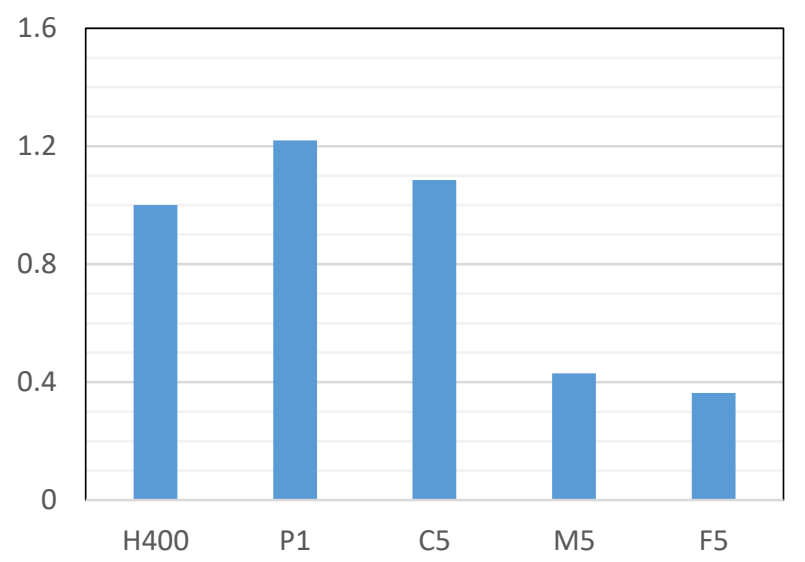

Fig. 8. Relative wear resistance $\varepsilon$ at AIEW test compared to Hardox 400

\section{CONCLUSIONS}

Based on our test results, composite hardfacings containing coarse hardmetal reinforcement suit well for use in the wear conditions where abrasion with fixed particles or two-body abrasion occur. 
1. At two-body abrasion or abrasion with fixed particles, hardfacings with 50 vol\% coarse angular hardmetal reinforcement content are most suitable.

2. At three-body abrasion hardfacings with 50 vol\% spherical hardmetal content are recommended.

3. At the abrasive impact erosion wear conditions, hardmetal reinforcement gives a detrimental effect to the wear resistance.

\section{Acknowledgments}

This research was supported by institutional research grant IUT19-29 "Multi-scale structured ceramic-based composites for extreme applications" of the Estonian Ministry of Education and Research and the Archimedes project AR 12132 "Wear Hard”.

\section{REFERENCES}

1. Kulu, P., Zimakov, S. Wear Resistance of Thermal Sprayed Coatings on the Base of Recycled Hardmetal Surface Coatings Technology 130 (1) 2000: pp. 46-51 https://doi.org/10.1016/S0257-8972(00)00687-3

2. Kulu, P., Halling, J. Recycled Hard-metal-based Wearresistant Composite Coatings Journal of Thermal Spray Technology 7 (2) 1998: pp. 173-178. https://doi.org/10.1361/105996398770350882

3. Kulu, P., Surzhenkov, A., Tarbe, R., Viljus, M., Saarna, M., Tarraste, M. Hardfacings for Abrasive Wear Applications Proceedings of the 28th International Conference on Surface Modification Technologies 2014: pp. 149-157.

4. Ishida, T., Itakura, T., Moriguchi, H., Ikegava, A. Development of Technologies for Recycling Cemented Carbide Scrap and Reducing Use in Cemented Carbide Tools SEI Technical Review 75 2012: pp. 38-46.

5. Bendikiene, R. Ciuplys, A., Pupelis, E. Research on Possibilities to Replace Industrial Wear Plates by Surfaced Coatings Using Waste Materials International Journal of Surface Science and Engineering $10(4)$ 2016: pp. $330-338$. https://doi.org/10.1504/IJSURFSE.2016.077535

6. Badisch, E., Kirchgaßner, M. Influence of Welding Parameters on Microstructure and Wear Behaviour of a Typical Nicrbsi Hardfacing Alloy Reinforced with Tungsten Carbide Surface and Coatings Technology 202 (24) 2008: pp. 6016-6022. https://doi.org/10.1016/j.surfcoat.2008.06.185

7. Zikin, A., Antonov, M., Hussainova, I., Katona, L., Gavrilović, A. High Temperature Wear of Cermet Particle Reinforced NiCrBSi Hardfacings Tribology International 68 2013: pp. 45-55.

https://doi.org/10.1016/j.triboint.2012.08.013

8. Ming-xi, L., He, Y., Sun, G. Laser Cladding Co-based Alloy/SiCp Composite Coatings on IF Steel Materials \& Design 25 (4) 2004: pp. 355-358. https://doi.org/10.1016/j.matdes.2003.08.006

9. Bolelli, G., Bonferroni, B., Laurila, J. Lusvarghi, L., Milanti, A., Niemi, K., Vuoristo, P. Micromechanical Properties and Sliding Wear Behavior of HVOF-sprayed Febsed Alloy Coatings Wear 276-277 2012: pp. 29-47. https://doi.org/10.1016/j.wear.2011.12.001

10. Li, R., He, Y.D., Zhou, Z., Wang, Z.J., Song, X.Y. Wear and High Temperature Oxidation Behaviorof Wire Arc Sprayed Iron Based Coatings Surface Engineering 30 (11) 2014: pp. $784-790$. http://dx.doi.org/10.1179/1743294414Y.0000000331

11. Zikin, A., Ilo, S., Kulu, P., Hussainova, I., Katsich, C., Badisch, C. Plasma Transferred ARC (PTA) Hardfacing of Recycled Hardmetal Reinforced Nickel-matrix Surface Composite Materials Science (Medziagotyra) 18 (1) 2012: pp. $12-17$ http://dx.doi.org/10.5755/j01.ms.18.1.1334

12. Bendikiene, R., Ciuplys, A., Kavaliauskiene, $\mathbf{L}$. Preparation and Wear Behaviour of Steel Turning Tools Surfaced Using the Submerged Arc Welding Technique Proceedings of the Estonian Academy of Sciences 65 (2) 2016: pp. $117-122$. http://dx.doi.org/10.3176/proc.2016.2.01

13. Simson, T., Kulu, P., Surženkov, A., Tarbe, R., Viljus, M., Tarraste, M., Goljandin, D. Optimization of Reinforcement Content of Powder Metallurgy Hardfacings in Abrasive Wear Conditions Proceedings of the Estonian Academy of Sciences 65 (2) 2016: pp. 90-96. http://dx.doi.org/10.3176/proc.2016.2.03

14. Simson, T., Kulu, P. Surženkov, A., Goljandin, D., Tarraste, M., Viljus, M. Optimization of Composition of Hardmetal Reinforced Fe-Based PM Hardfacings in Abrasive Wear Conditions Key Engineering Materials 721 2017: pp. $351-355$.

15. Castolin Eutectic homepage, CDP112 wear plate data, https://www.castolin.com/product/cdp-112, 02.02.2017.

16. ASTM G65-16, Standard Test Method for Measuring Abrasion Using the Dry Sand/Rubber Wheel Apparatus.

17. Talviste, K. Strengthening Technologies for Road Maintenance Machinery Wear Parts MSc thesis Tallinn University of Technology, 2013 (in Estonian).

18. GOST 23.201-78, Gas Abrasive Wear Testing of Materials and Coatings with a Centrifugal Accelerator.

19. Mechanical and Metal Trades Handbook, Verlag EuropaLehrmittel

20. Sapate, S.G., RamaRao, A.V. Erosive Wear Behaviour of Weld Hardfacing High Chromium Cast Irons: Effect of Erodent Particles Tribology International 39 (3) 2006: pp. 206-212. https://doi.org/10.1016/j.triboint.2004.10.013

21. EITobgy, M.S., Ng, E., Elbestawi, M.A. Finite Element Modeling of Erosive Wear International Journal of Machine Tools and Manufacture 45 (11) 2005: pp. 1337-1346. https://doi.org/10.1016/j.ijmachtools.2005.01.007 